\title{
The Resilience of Non-Sharia Compliant Company in Indonesia Stock Exchange (IDX) and its Determinants: Evidence from 2005-2013
}

\author{
Ibnu Qizam, Misnen Ardiansyah, and Abdul Qoyum \\ State Islamic University Sunan Kalijaga Yogyakarta Indonesia \\ qzami68@gmail.com, misnen_ardy@yahoo.com,qoyum13@gmail.com
}

\begin{abstract}
The aims of this study were to examine the resilience of non-sharia stock in Indonesia, to measure the impact of macro-economic variables and microcompany specific factors toward resilience. All the data, including 30 nonsharia companies in Indonesia, are retrieved from Indonesia Stock Exchange and Bloomberg database. Our dataset spans from 2005 to 2013, the study employs GMM Estimation Approach to estimate the determinants of company's resilience in Indonesia. The results find that profitability ratios ( $R O E, R O I C$, NIM), liquidity ratio (CASHR, CURR), debt asset ratio, and lagged dependent variable (Mertonit-1) are found to be statistically significant determinants of Merton distance-to-default. The company size is not a good predictor of the default risk for companies observed. This study emphasizes the benefits of using several accounting-based measures in company-default prediction models.
\end{abstract}

Keywords: Non-Sharia Stock, Stock Resilience, Probability Default, Distanceto-Default

\begin{abstract}
Abstrak
Tujuan dari penelitian ini adalah untuk menguji ketahanan stok nonsyariah di Indonesia, mengukur dampak variabel makroekonomi dan faktor spesifik perusabaan mikro terhadap ketahanan. Semua data, berjumlah 30 perusahaan non-syariah di Indonesia yang diambil dari Bursa Efek Indonesia dan database Bloomberg dari tabun 2005 sampai 2013, Studi ini menggunakan Pendekatan Estimasi GMM untuk memperkirakan faktor penentu ketahanan perusabaan di Indonesia. Hasilnya menemukan babwa rasio profitabilitas (ROE, ROIC, NIM), rasio likuiditas (CASHR, CURR), rasio butang, danvariabel dependen yang tertinggal (Mertonit-1) ditemukan sebagai faktor penentu signifikan Merton dari jarak ke standar. Ukuran perusahaan bukanlah prediktor yang baik dari risiko Default bagi perusabaan yang diobservasi. Penelitian ini menekankan manfaat menggunakan beberapa pengukuran berbasis akuntansi dalam model prediksi Default perusabaan.
\end{abstract}

Kata Kunci: Stok Non-Sharia, Stock Resilience, Probability Default, Distanceto-Default.

Permalink/DOI:http://dx.doi.org/10.18326/infsl3.v11i2.269-290 


\section{Introduction}

Historically, there are two crucial financial crises in the last two decades, namely the financial crisis in 1997 and 2008. In 1997, the East Asian Financial Crisis of 1997 and 2008 is the Global Financial Crisis. Crisis in 1997 was caused by a lack of transparency and credibility of the government that led to structural and policy distortions (Raz et al., 2012 and Corsetti et al., 1999). During the 1997/98 Asian financial crisis, the Indonesia's economy plunged into deep recession in 1998 with overall growth at minus 13.7 percent, which was very serious compared with less than 5 percent contraction during the difficult times in the 1960s (Tambunan, 2011).

Whereas, the crisis of 2008 was triggered by the rapid innovation in financial products such as securitization practices and was also compounded by property speculation and inaccurate credit ratings. During the October-December 2008 period, the country's economy experienced deteriorating economic performance at an unprecedented speed. Overall growth rate for 2008 was 6.2 percent, a slightly decline from 6.3 percent in 2007. By the end of 2008, the Coordinating Ministry for Economic Affairs stated that Indonesian economy would grow only 5 per cent in 2009. Recently, however, the prediction has been downward revised to 4.5-5.5 percent with a base case at 5 percent. In 2010, economic growth is expected to recover to the 5.5 percent-6.0 percent range. In summary, Indonesia's economy during the crisis of 2008 still showed some resilience towards the crisis (Tambunan, 2011).

Both crisis would have a macroeconomic impact, which has, in turn, also affected the stocks (see Gitman, 2006: 770). This fact is supported by the factual data in which stock market is one of the most improving sectors in Indonesian economy. Stock resilience is considered as an important tool to identify the quality of companies in Indonesia. It means that the higher resilient the country's economy is, the better stock market will be. 
So far, there is a little empirical evidence (according to the author's observation) that tries to test the level of stock's resilience in Indonesia, and to what extent the impact of financial crisis (i.e. the financial crisis of 2007 and the global financial crisis of 2008) affects the resilience levels of non-sharia stock.

The objective of this study is to test, empirically, whether non-sharia stock has good resilience to encounter the global financial crisis. In addition, this research also aims to identify the determinants of stock resilience in Indonesia Stock Exchange (IDX). This research is very important because the results of an empirical resilience of non-sharia stocks can be used as a basis for evaluating financial performance, for example, to be aware to the soundness of non-sharia stock as an early warning system on the impact of the global financial crisis for non-sharia stock.

In addition, this result is expected to be used as a basis for developing sharia-compliant stock in Indonesia. The results of this study are expected to enrich the science related to resilience of non-sharia stock. Moreover, for policy makers, this research is expected to be a reference in drafting regulations relating to aspects that need to be considered by companies/issuers in maintaining its financial resilience to deal with the financial crisis. In addition, this research is expected to be used by management, creditors, investors or other for business decision making, particularly in dealing with how to keep his company on having resilience in the face of global financial turmoil.

\section{Literature Review}

\section{Financial Instability}

Davis (2001) states that there are several theories that explain financial instability, namely: 1) the theory of debt and financial fragility, 2) the theory of disaster myopia, and 3) the theory of bank runs. Debt and financial fragility theory argues that the economy follows a cycle consisting of positive and negative growth period (Fisher, 1933). With the advancement of economic, debt and increased risk-taking activities, it creates an asset bubble that will lead to negative growth. Meanwhile, disaster myopia theory 
shows that financial instability can be caused by the competitive behaviour of financial institutions which lead to a condition in which the credibility of the borrower is ignored and the risks are reduced (Herring, 1999). On the other hand, the theory of bank runs explains the conditions whereby the investors who are panic and then sell their assets or withdraw their funds for their fear to the economic conditions that will worsen (Diamond and Dybvig, 1983; Davis, 1994). As a consequence, this will lead to a sudden decline in asset prices and create liquidity crisis.

The three theories above can actually explain the 1997 East Asian Financial Crisis. Financial deregulation with inadequate regulatory oversight will lead to the asset bubbles and, thus cause negative economic growth in East Asian economies. Meanwhile, the rapid credit expansion could also cause the crisis due to the loans which is extended to bankrupt debtor in order to improve profitability. Last but not least, when investors realize that the situation is bad, they withdraw their funds, leading to large capital outflows.

In addition to these basic theories, some literature suggests that financial instability can also be caused by the role of international capital flows through international transmission, such as the pattern of trade, exchange rate pressures and foreign investment, which lead to "contagion effect" (see e.g. Chongvilaivan, 2010; Davis, 2001). For example, the Global Financial Crisis in 2008 is actually triggered by the crisis "subprime" beginning in the United States. From the financial crisis in the US, as explained by the above theories, the global financial turmoil spreads to other areas, including East Asia. All areas go worse, due to the contagious effects of the "subprime mortgage" crisis.

According to Ridwan (2011), after the subprime mortgage, none of the developed countries in the world that escapes from the global financial crisis turbulence. It can be seen that after "subprime mortgage" crisis, the US economic growth fell to minus 2.51 per cent. European countries such as Britain, Germany and France economic growth also fell respectively to minus 4.1 per cent, minus 3.8 per cent, and minus 3.2 per cent. 
The same thing befalls Asian developed countries, such as Japan's economic growth in 2009 falling to the level of minus 9.7 per cent while Korea somewhat goes up slightly compared to Japan. In the same year, Korea's economic growth is positive 0.1 per cent, previously suffering negative growth. In addition, India is one of the Asian Countries that can restore quickly in term of economic growth, from 4.5 per cent increase in 2008 to 5.8 per cent in 2009 while China's economic growth goes slower, from $6.8 \%$ to 6,1 per cent (Bappenas, 2010).

In addition, Raz et al. (2012) have revealed important findings regarding the main impact of the financial crisis in East Asian economies. First, Raz et al. (2012) have investigated the impact of the East Asian Financial Crisis of 1997 and the Global Financial Crisis of 2008. The results show that although the crisis has the opposite effect on the economy in the region, the East Asian economies have become stronger during the crisis in 2008 compared to the crisis in 1997. Second, this paper finds that the reduced impact of the crisis in 2008 occurs because, in addition to the nature of externality crisis, most economies in East Asia have been taking lessons after the East Asian financial crisis in 1997 to strengthen economic fundamentals, supported by the better credibility and accountability of government. In addition, in 2008, Asian countries have better economic fundamentals, indicated by a better macro-economic condition.

There are many researches on the problem of resilience. Vassalou and Xing (2003) examine the study of the rate of equity return and its relationship with default probability. Using the Merton model (1974), this study finds that the size and value of book to market is closely related to the risk of default while Trussel (1999) studies the resilience of the company by trying to find a relationship between bond rating companies and components of the Black Scholes model. The study concludes that face-value loan, firm size and asset variance can be explained by bond ratings. In addition, Hillegeist (2002) compares the bankruptcy prediction model of accounting information base (Z-score and O-score) and Merton model. The result of the research is that Merton model has better ability to predict the default probability than accounting information, i.e., Z-Score and O-Score (see also Beaver, 1966). 
Charkau (2006) also tries to compare Merton model with Accounting Information model with credit rating company. The finding is that Merton's Model can explain additional information better than Z-score and O-score. Tudela and Young (2004) use the Merton model to predict the company's default probability in the UK. The researchers find that Merton model estimates are good enough to predict and explain the companies that fail to pay or do not fail.

Manurung (2008) uses the Merton model to predict the probability of default firms listed in LQ-45 in Indonesia. The results show that companies that have high stock liquidity also have the opportunity to default. Companies in the financial sector have a higher probability of default than other sectors. Well, Tobing and Manurung (2009) also try to analyse the probability of default based on the Merton model. The study finds that some large companies have a high probability of default, especially Bakrie and Brothers. Panel regression results show that the cash to current assets ratio and the solvency ratio (debt to asset ratio) are the most important ratios to explain the default probability. Profitability ratios (net profit margin ratio) can also be a good measure to predict the probability of a Merton default.

$\mathrm{Qu}$ (2008) examines the relationship between macroeconomic variables and default probabilities. The results find that some results have been documented. In Sweden, there are some macro-factor changes such as industrial production, interest rate spread, exchange rate, and stock price that affect probability of default. However, these results cannot be used to generalize cases in other countries, as these impacts vary across countries.

\section{Capital Market}

Capital markets as part of the conventional economic system, the capital market is inseparable from one of the most serious problems in its operations. One is the act of speculation. Speculation is an activity that buys stocks in order to gain profit in the short run. This advantage can be obtained from the difference in stock prices when buying by selling. This activity becomes an 
integral part and cannot be separated from the existence of the stock market nowadays.

In this capital market, the difference between the speculator and the business (investor) derives from the uncertainty he faces. To this point, it is necessary to see the character of each investment and speculation: first, investors in the capital market are those who utilize the capital market as a means to invest in publicly traded companies are believed to be good and profitable, not for the purpose of seeking capital gain through short selling. They underlie their investment decisions on reliable information about the fundamental factors of the economy and the company itself through careful study. Meanwhile, speculators aim at getting a gain that is usually done with the effort of "frying" stock.

Second, real speculation is not an investment, although there are similarities between the two. The very basic difference between the two lies in the underlying motivation. The speculators buy securities for a gain (capital gain) by reselling them in the short term while investors buy securities with the aim to participate directly in business that is usually long term.

In Islam itself, there are many differences about whether or not speculation is allowed. In the the Quran, what is clearly forbidden is the activities of Maysir and Gharar. The buying and selling done with gharar elements is clearly prohibited because it will bring madharat. The existence of this gharar leads to the potential maysir. Maysir is more like gambling or zero-sum game.

"They will ask you about liquor and gambling.Let say: In the second there is a great evil as well as some benefit to mankind, but the crime they cause is greater than the benefit they bring" Quran (2: 219)

Rasulullah (SAW) also forbids us from gambling as depicted in the following hadith;

"From Abu Hurairah (RA), that he says," Allah's Apostle (S) forbids 'sale of gravel' [the object] [sale of objects selected or determined by pebble throwing], and al-gharar sale [Sabih Muslim] 
There are differences of opinion from the scholars about whether or not the activities of speculation are included as part of maysir. Ibn Taymiyyah argues that the above hadith is a hadith about gharar as a consequence of ignorance. Maysir or gambling is forbidden in Islam for causing hostility and hatred and also involves consuming the property of bi-al-batil, which is a type of oppression. Given a clear ban on gambling in the Qur'an and the Prophet's Hadith (SAW), it is very important to determine whether or not the speculation in the stock market is similar to gambling.

Kamali (1996) defines speculation as comprising "smart and rational forecasting of future asset price trends based on evidence and knowledge of past and present conditions". Based on Quranic verses and Hadith of the Prophet (SAW), Ibn Taimiyyah (ra) says that if sales contain gharar and eat the property of others, it is the same as gambling, which is clearly prohibited. Therefore, for transactions to be equated with gambling, it must involve devouring and unlawful possession of others. The speculative risk of taking in trading, which involves investment of assets, skills and labor is not the same as gambling. This is because buyers engage in transactions aimed at making profits through trade and not through the honest plunder of the property of others.

Meanwhile, El-Ashkar (1995) defines speculation as a practice that uses available information to anticipate future price movements of a securities so that the act of buying or selling securities may be taken with the intent to buy or sell securities to gain capital gains and/or to maximize stock capitalization value. It is a process that relies on the analysis of many economic and financial data, corporate financial statements, political decisions, information on management skills and talents and personal profiles of decision makers. Overall, speculation is an activity that requires a lot of knowledge and skills.

Therefore, based on some opinions above, then the speculation in the stock market can not be equated with gambling. This is because speculation in the stock market is still based on the knowledge, science and economic data available to make decisions. The sale of gharar is said to cause maysir (gambling) 
which causes oppression and is therefore prohibited in Islam. It is clear that gharar is not present in the stock market speculation as each party is clear with the quantity, specification, price, time and place of delivery of the object. In addition, transaction objects, i.e., security purchased, are available in the market at the time of the transaction and, will surely be available upon delivery. Therefore, speculation has no gharar element and, therefore, does not cause maysir.

The above discussion has proved that although speculation in the stock market may look like gambling, it does not mean the same as gambling. The positive side is that it can help stabilize prices and activate markets when there is a thin trade. It can also signal to less informed investors on it to act. The negative effect of speculation is that excessive amounts can lead to stable price movements in the market. Thus it can be concluded that excessive speculation should not be allowed, but a reasonable level is permitted. Quantitative limits on daily trading volume and legislative guidance may help to contain speculation within healthy boundaries. There is also a view that Islamic teachings expressly prohibit this act of speculation, for it is diametrically opposed to the divine and insane values. This action also triggers the occurrence of fraudulent acts that occur in stocks such as the occurrence of Ponzi scheme, frauds in trading or short selling.

\section{Merton Model}

Merton model (1974) is very robust model in finance theory aplied to measure the default probability of the firm. According to this theory, default is triggered when the underlying assets reach the default threshold, or in other words, company can be categorized in default situation is if the company's assets are below the face value of the debt at maturity date (Jones and Hanser, 2008).

The total market value of the firm's asset at the time $\mathbf{t}, V_{t}$, is assumed to follow a standard diffusion process of the following form: 


$$
\frac{d V t}{V t}=(\mu-D) d t+\sigma d z
$$

Where $\mu$ denotes the expected total rate of return on the firm's asset value (subsequently 'expected asset return' $\mu$ ) reflecting the business prospects (equal to the risk free rate, $r$, plus an asset risk premium), $D$ is the total payout rate by the firm to all its claimant (including dividends to equity-holders and interest payment to debt holders) expressed as a percentage of of $V, \sigma$ is the business volatility or standard deviation of a firms asset returns (percentage asset value changes), and $d z$ is an increment of a standard wiener process.

Recall that the holders of a firm's equity have a residual claim on the firm assets at the same time as they have limited liability. Merton (1974) recognizes that this makes a firm's equity equivalent to a long position in call option on the firm's assets and uses this equivalent to derive the market value and volatility of the firm's underlying assets.

The Merton model is derived from by treating the value of leveraged equity as a call option on the assets of the firm.

$$
V_{E}=V_{A} N\left(d_{1}\right)-e^{-r(T-t)} D N\left(d_{2}\right)
$$

Where $V_{E} V_{E}$, is the value of equity, $V_{A} V_{A}$ is the value of asset and $\mathrm{D}$ is the face value of debt. (T-t) is the time to maturity of debt, $r$ is the risk-free rate

$$
\begin{aligned}
& d_{1}=\frac{\ln \left(\frac{V_{A}}{D}\right)+\left(r+\frac{1}{2} \sigma_{A}^{2}\right)(T-t)}{\sigma_{A} \sqrt{(T-t)}} \\
& d_{2}=d_{1}-\sqrt{(T-t)}
\end{aligned}
$$


And $\mathrm{N}$ (.) is the function for cumulative normal distribution. To calculate $\sigma_{A} \sigma_{A}$ we adopt an iterative procedure. We use daily data forms the past 12 month to obtain an estimate of the volatility of equity $\sigma_{E} \sigma_{E}$, which is then used as an initial value for the estimation of $\sigma_{A} \sigma_{A}$ Using Black-Scholes formulas, and for each trading day of the past 12 month, we compute $V_{A} V_{A}$ using $V_{E} V_{E}$ as the market value of equity of that day. In this manner, we obtain daily values for $V_{A} V_{A}$. This then used to compute the standard deviation of those $V_{A}, S V_{A}, S$, which is used as the value of $\sigma_{A} \sigma_{A}$, for the next iteration. That procedure is repeated until the value of $\sigma_{A} \sigma_{A}$, from the two consecutive iteration converge.

This approach also provides a relationship between equity and asset return volatility:

$$
\sigma_{E}=\frac{V_{A}}{V_{E}} N\left(d_{1}\right) \sigma_{A}
$$

Once daily value of $V_{A} V_{A}$ are estimated, we can compute the drift $\mu \mu$, by calculating the mean of change in $\ln V_{A} V_{A}$.

The default probability is the probability that the firm's assets will be less than book value of the firm's liabilities. In the other word,

$$
P_{d e f, t}=\operatorname{Prob}\left(V_{A, t+T} \leq \frac{D}{V_{A, t}}\right)=\operatorname{Prob}\left(\ln \left(V_{A, t+T}\right) \leq \ln (D) / V_{A, t}\right)
$$

Since the value of assets follows the GBM of equation, the value of the assets at any time $t$ given by:

$$
\begin{gathered}
\ln \left(V_{A, t+T}=\ln \left(V_{A, t}\right)+\left(\mu-\frac{\sigma_{A}^{2}}{2}\right)(T-t)+\sigma_{A} \sqrt{(T-t) \varepsilon+T}\right. \\
\varepsilon_{t+T}=\frac{W(t+T)-W(t)}{\sqrt{T}} \text { and } \varepsilon_{t+T} \sim N(0,1) .
\end{gathered}
$$

Therefore we can write the default probability as follow:

$$
P_{\text {def }, t}=\operatorname{Prob}\left[\ln \left(V_{A, t}\right)-\ln (D)+\left(\mu-\frac{\sigma_{A}^{2}}{2}\right) T+\sigma_{A} \sqrt{T_{\varepsilon_{t+T}}} \leq 0\right]
$$




$$
P_{d \theta f, t}=\operatorname{Prob}\left(-\frac{\ln \left(\frac{V_{A, t}}{D}\right)+\left(\mu-\frac{\sigma_{A}^{2}}{2}\right) T}{\sigma_{A} \sqrt{T}} \geq \varepsilon_{t+T}\right.
$$

Then we can define the distance to default (DD), as follow;

$$
D D=\frac{\ln \left(\frac{V_{A, t}}{D}\right)+\left(\mu-\frac{1}{2} \sigma_{A}^{2}\right) T}{\sigma_{A} \sqrt{T}}
$$

Default occurs when the ratio of the value of asset to debt is less than 1, or its log is negative. The $D D$ tells us by how many standard deviations the log of this ratio needs to deviate from its mean in order for default to occur. We use Vassalu and Yuhang method that use Merton models, i.e., the theoretical distribution implied by Merton's model, which is the normal distribution. In this case, the theoretical probability of default will be given by:

$$
P_{\text {def }}=N(-D D)=N\left(-\frac{\ln \left(\frac{V_{A, t}}{D}\right)+\left(\mu-\frac{1}{2} \sigma_{A}^{2}\right) T}{\sigma_{A} \sqrt{T}}\right)
$$

\section{Methodology}

\section{Data}

All data to construct the indicators for an accounting information and merton distance-to-default were retrieved from Bloomberg database. We included 30 non-sharia companies in Indonesia. Our dataset spanned from 2005 to 2013. The research used a set of different variables to measure the determinants of merton distanceto-default. This research took the variables of profitability ratios (i.e return on equity, ROE; return on investment capital, ROIC; and net income margin, NIM), liquidity ratios (cash ratio, CASHR, and current ratio, CURR), debt to asset ratio (TDTA), and we useed log total assets to measure the company size. Table 1 below depicts the accounting information used in this research and the sources. 
Table 1.

Accounting information and Sources of the Data

\begin{tabular}{|c|c|c|c|c|}
\hline No & Variables & Symbol & Indicators for & Source \\
\hline 1 & Return on Equity & $R O E$ & Profitability & Bloomberg \\
\hline 2 & $\begin{array}{l}\text { Return on Investment } \\
\text { Capital }\end{array}$ & $\mathrm{ROIC}$ & & Bloomberg \\
\hline 3 & Net income margin & NIM & & Bloomberg \\
\hline 4 & Cash Ratio & CASHR & Liquidity & Bloomberg \\
\hline 5 & Current Ratio & CURR & & Bloomberg \\
\hline 6 & Total Debt to Total Asset & $T D T A$ & Debt to Asset & Bloomberg \\
\hline 7 & Log Total Asset & $\operatorname{LnTA}$ & Size & Bloomberg \\
\hline
\end{tabular}

\section{GMM Estimation Approach}

To address the fixed effect issues, and because of the lagged dependent variable and heteroscedasticity present in the data, we estimated the model using an Arellano-Bond difference GMM (GMM-dif). The Arellano-Bond difference GMM estimator is specifically designed for panels with large-N and short-T. In that we specify our model as:

$$
\begin{aligned}
\text { MERTON }= & \text { MERTON } \\
& \beta_{6} \text { TDTA }+\beta_{7} \text { LnTA }+\beta_{1} \text { ROE } \beta_{6} \text { TDTA } \beta_{2} \text { ROIC }+\beta_{7} \text { LnTA }+
\end{aligned}
$$

The dynamic Generalized Method of Moment (GMM) is an instrumental variable estimator that employs lagged values of all endogenous variables as well as lagged variables as the instruments. The model can be estimated using the levels or the first difference of variables. Arrellano and Bond (1991) propose an idea of two estimators---one step and two step estimators---to become the optimal estimator. Nonetheless, there is likelihood for two-step estimator to underestimate the standard errors of estimates, in turn, providing wrong information in drawing a conclusion. To tackle this issue, the common practice is to estimate with twostep estimator but base hypothesis testing according to one-step estimator's statistics. In doing so, we need to satisfy some of the requirements, e.g., there is no second order serial correlation in our GMM model. If there is any, it will render the GMM instruments invalid. The diagnostic tests for GMM estimator are sargan test of 
over identifying restrictions and the test of lack of residual serial correlation. For the sargan test, it is according to the sample analogue of the moment conditions employed in the estimation process and examining the validity of the instruments.

\section{Findings and Discussion \\ Descriptive Statistics}

Table 1 below shows the descriptive statistics of a set of different variables of merton default to distances and accounting information for non-sharia companies in Indonesia. To begin with, the mean of default probabilities based on merton model is 0.7118 with the range swinging from 0.2480 to 1.00 . For profitability proxies, as depicted by ROE, ROIC, and NIM, the descriptive statistic produces a consistent result in which the non-sharia companies have higher level of average profitability level. However, the profitability measurements for the companies observed are quite volatile. The non-sharia companies in Indonesia have ROE ranging from -255.92 to $171.38 \%$ with the average of 13.93 . Similarly, the ROIC swinging from -9.81 to $43.06 \%$ with the mean of $12.15 \%$, while the NIM lies between -244.13 to $65.51 \%$ with the average of $7.23 \%$.

Subsequently, we shows the liquidity ratio as depicted by cash ratio (CASHR) and current ratio (CURR). CASHR lies between 0 to $121.97 \%$ with the mean of $1.98 \%$, while the CURR ranges from 0.09 to $455 \%$ with the average of $10.22 \%$. As indicator for financial leverage, debt to asset ratio (TDTA), we find that the TDTA have the range between 0.00 to $144.85 \%$ with the mean of $22.87 \%$. For total assets (TA), our observation shows that the companies have the average TA of $\$ 65,900,000$.

Table 2

Descriptive statistics of non-sharia companies

\begin{tabular}{cccccc}
\hline Variables & $\begin{array}{c}\text { Number of } \\
\text { observations }\end{array}$ & Mean & Std. Dev & Min & Max \\
\hline Merton & 270 & 0.7118 & 0.2162 & 0.2480 & 1.0000 \\
ROE & 258 & 13.9324 & 31.3370 & -255.9200 & 171.3800 \\
ROIC & 222 & 12.1531 & 8.8644 & -9.8100 & 43.0600 \\
NIM & 264 & 7.2330 & 35.9104 & -244.1300 & 65.5100 \\
CASHR & 177 & 1.9825 & 10.9694 & 0.0000 & 121.9700 \\
CURR & 177 & 10.2291 & 42.6355 & 0.0900 & 455.0500 \\
TDTA & 265 & 22.8742 & 21.7667 & 0.0000 & 144.8500 \\
TA & 270 & 65900000 & 126000000 & 352 & 733000000 \\
& & & & & \\
\hline
\end{tabular}


Pairwise comparison matrix has been incorporated in this study to see, at a glance, the correlation among the variables observed. No multicollinearity issues are evidenced. In addition, the highest is 0.7861 between ROIC and ROE while the lowest correlation falls between total assets and net income margin with -0.0023 . More specifically, for Merton default-to-distance, the highest correlation is 0.1121 between CURR and Merton. The lowest correlation, in contrast, falls between debt to asset ratio of -0.5498

Table 3.

Correlation Matrix

\begin{tabular}{ccccccccc}
\hline & Merton & ROE & ROIC & NIM & CASHR & CURR & TDTA & TA \\
\hline Merton & 1 & & & & & & & \\
ROE & $-0.184^{*}$ & 1 & & & & & & \\
ROIC & $-0.1239^{*}$ & $0.7861^{*}$ & 1 & & & & & \\
NIM & $0.0358^{* *}$ & $0.1935^{* *}$ & $0.1042^{* *}$ & 1 & & & & \\
CASHR & $0.0397^{* *}$ & $-0.1554^{* *}$ & -0.0166 & $-0.1782^{* *}$ & 1 & & & \\
CURR & $0.1121^{* *}$ & $-0.2211^{* *}$ & -0.2268 & $-0.1455^{* *}$ & $0.4766^{* *}$ & 1 & & \\
TDTA & $-0.5498^{* *}$ & 0.1709 & $-0.0744^{*}$ & $0.0752^{*}$ & $-0.2799^{*}$ & $-0.2986^{*}$ & 1 & \\
TA & $0.0753^{* *}$ & $0.121^{*}$ & $-0.0023^{*}$ & $-0.009^{*}$ & $-0.1006^{*}$ & $-0.0807^{*}$ & $0.0683^{*}$ & 1 \\
\hline
\end{tabular}

Notes: Table reports pairwise correlation coefficient for the companies observed. No multi collinearity problems are evidenced. Table reports significance level for hypotheses test $\mathrm{H0} ;$ rho $=0 ; *$ significance at alpha $1 \%, * *$ significance at alpha $5 \%$.

\section{Merton Default to Distance}

In this part, we report the merton default-to-distance for the period 2005 to 2013 to have a first understanding of the merton distance-to-default for the samples observed. At first, in most cases, the default probability of non-sharia companies observed is greater than 0.5 . The highest default probability for companies observed is Bank Central Asia (BCA) of 1.00 for the year 2005 to 2007 and 2009 to 2012, almost consistent for the years observed. This findings are consistent with the study of Konstituanto et al. (2011) which reveals that the BCA has the highest probability to default among the banks observed in year 2006 to 2009. They also 
indicate that BCA has the highest level of volatility for the share price among the sample observed. On the other hand, the lowest default probability in our study falls in Berlian Laju Tankers Tbk of 0.2480 for the year 2012. This company has the lowest probability level with the range of 0.2480 to 0.6220 .

Table 3.

Merton default-to-distance period 2005 to 2013

\begin{tabular}{|c|c|c|c|c|c|c|c|c|c|}
\hline No Comparies & 2005 & 2006 & 2007 & 2008 & 2009 & 2010 & 2011 & 2012 & 2013 \\
\hline $1 \mathrm{BISI}$ & 0.7504 & 0.6872 & 0.7689 & 0.7155 & 0.8286 & 0.9543 & 0.9120 & 0.9388 & 0.9372 \\
\hline 2 BUMTEKNOKULTUR & 0.7889 & 0.5663 & 0.6979 & 0.6065 & 0.4108 & 0.4055 & 0.4424 & 0.7888 & 1.0000 \\
\hline 3 BW PLANTATION & 0.5428 & 0.4456 & 0.3797 & 0.3982 & 0.4633 & 0.4172 & 0.4074 & 0.3923 & 0.4021 \\
\hline 4 CENTRAL PROTENA & 0.8144 & 0.6705 & 0.7012 & 0.6880 & 0.6754 & 0.6417 & 0.5267 & 0.4983 & 0.5954 \\
\hline 5 SAMPOERNA AGRO & 0.5784 & 0.6767 & 0.6905 & 0.7111 & 0.7521 & 0.7209 & 0.7061 & 0.6462 & 0.6277 \\
\hline 6 BAKRE SUMATERA & 0.4296 & 0.4040 & 0.4528 & 0.4461 & 0.4425 & 0.4172 & 0.4185 & 0.3978 & 0.3690 \\
\hline 7 BAKRELLAND DEV & 0.5860 & 0.5891 & 0.7008 & 0.6431 & 0.5542 & 0.6074 & 0.5954 & 0.6112 & 0.5912 \\
\hline 8 BAKRE TELECOM & 0.5930 & 0.6437 & 0.5240 & 0.6017 & 0.5192 & 0.5128 & 0.4811 & 0.4228 & 0.3650 \\
\hline 9 BAKRE \& BROTHER & 0.8287 & 0.8129 & 0.7033 & 0.6814 & 0.5953 & 0.6784 & 0.6826 & 0.6914 & 0.4202 \\
\hline 10 SMART TBK & 0.8592 & 0.8487 & 0.8375 & 0.8391 & 0.7761 & 0.7678 & 0.8044 & 0.8226 & 0.7203 \\
\hline 11 CITA MINERAL N & 0.3914 & 0.3705 & 0.4361 & 0.4910 & 0.5095 & 0.4738 & 0.4625 & 0.4787 & 0.4737 \\
\hline 12 CAKRA MINERAL TB & 0.7050 & 0.7302 & 0.4613 & 0.7408 & 0.6007 & 0.6894 & 0.7758 & 0.6495 & 0.7303 \\
\hline 13 ADIRA FINANCE & 0.4565 & 0.4124 & 0.4598 & 0.5620 & 0.5122 & 0.4511 & 0.3927 & 0.3853 & 0.3902 \\
\hline 14 BANK CENTRAL ASI & 1.0000 & 1.0000 & 1.0000 & 0.9999 & 1.0000 & 1.0000 & 1.0000 & 0.9999 & 0.9999 \\
\hline 15 BANK BUKOPN & 0.9990 & 0.9986 & 0.9995 & 0.9997 & 0.9998 & 0.9998 & 0.9994 & 0.9985 & 0.9993 \\
\hline 16 BANK NEGARA INDC & 0.9999 & 1.0000 & 0.9999 & 0.9999 & 1.0000 & 1.0000 & 1.0000 & 1.0000 & 0.9998 \\
\hline 17 BANK RAKYAT INDC & 0.9890 & 0.9906 & 0.9937 & 0.9939 & 0.9694 & 0.9866 & 0.9872 & 0.9939 & 0.9922 \\
\hline 18 BANK TABUNGANN] & 0.8756 & 0.8636 & 0.8768 & 0.9054 & 0.9004 & 0.9059 & 0.8922 & 0.9350 & 0.9444 \\
\hline 19 BANK DANAMON & 0.9945 & 0.9933 & 0.9927 & 0.9973 & 0.9990 & 0.9982 & 0.9943 & 0.9909 & 0.9941 \\
\hline 20 BANK MANDIRI & 0.9994 & 0.9992 & 0.9993 & 0.9997 & 0.9996 & 0.9999 & 0.9996 & 0.9997 & 0.9998 \\
\hline 21 BANK CIMB NIAGA & 0.5159 & 0.4927 & 0.4885 & 0.4922 & 0.4781 & 0.4707 & 0.4787 & 0.4801 & 0.4941 \\
\hline 22 BANK INTL NDON & 0.6678 & 0.6468 & 0.6271 & 0.6041 & 0.5947 & 0.5904 & 0.5912 & 0.5716 & 0.5863 \\
\hline 23 ACE HARDWARE & 0.4763 & 0.4465 & 0.6864 & 0.7285 & 0.7815 & 0.7213 & 0.7191 & 0.7166 & 0.6515 \\
\hline 24 ADHI KARYA & 0.6056 & 0.5735 & 0.5390 & 0.5496 & 0.5289 & 0.5521 & 0.5516 & 0.5403 & 0.5662 \\
\hline 25 POLYCHEM INDONE؟ & 0.9905 & 0.9872 & 0.9811 & 0.9705 & 0.9741 & 0.9816 & 0.9966 & 0.9973 & 0.9992 \\
\hline 26 TIGA PILAR FOOD & 0.4128 & 0.4001 & 0.4409 & 0.4287 & 0.4259 & 0.4175 & 0.4552 & 0.4622 & 0.4703 \\
\hline 27 ASTRA NTERNATIO & 0.6935 & 0.6992 & 0.7158 & 0.7316 & 0.7415 & 0.7240 & 0.7029 & 0.7090 & 0.7227 \\
\hline 28 ASTRA OTOPARTS & 0.8129 & 0.8066 & 0.8383 & 0.8592 & 0.8673 & 0.8703 & 0.8221 & 0.7779 & 0.8884 \\
\hline 29 SENTUL CITY TBK & 0.8142 & 0.9030 & 0.9472 & 0.9299 & 0.8849 & 0.9152 & 0.9240 & 0.9077 & 0.8204 \\
\hline 30 BERLIANLA & 0.5865 & 0.6220 & 0.5079 & 0.5716 & 0.5303 & 0.5361 & 0.2667 & 0.2480 & 0.3118 \\
\hline
\end{tabular}




\section{Determinants of Merton distance-to-default measures (GMM Approach)}

After completion of calculating merton distance-to-default, in this part, we attempt to address the determinants of default probability. In that, we use generalized method of moments (GMM) to generate consistent, normal, and efficient of all estimators contained in the moment to be kept consistent. Our data consist of large number of cross-section units (30 samples) with small number of time periods ( 9 years). We measure, more specifically, several accounting information regressed on merton distanceto-default. Table 4 below shows the result of GMM estimation approach for several horizons.

\section{Table 4.}

GMM results of determinants of Merton distances-to-default period 2005-2013

\begin{tabular}{clll}
\hline Variable & \multicolumn{1}{c}{$\begin{array}{c}\text { One-step difference } \\
\text { GMM }\end{array}$} & \multicolumn{1}{c}{$\begin{array}{c}\text { Two-Step Difference } \\
\text { GMM }\end{array}$} & \multicolumn{1}{c}{$\begin{array}{c}\text { Two-Step Difference } \\
\text { GMM with robust SE }\end{array}$} \\
\hline MERTON it-1 & $0.0647(2.96)^{* *}$ & $0.0189(2.29)^{* *}$ & $0.0189(0.01)$ \\
ROE & $0.0010(2.43)^{* *}$ & $0.0008(4.46)^{* * *}$ & $0.0008(0.18)$ \\
ROIC & $-0.0014(-2.16)^{* *}$ & $-0.0012(-3.25)^{* * *}$ & $-0.0012(-0.29)$ \\
NIM & $-0.0011(-2.45)^{* *}$ & $-0.0009(-5.25)^{* * *}$ & $-0.0009(-0.19)$ \\
CASHR & $0.0166(3.86)^{* * *}$ & $0.0181(8.85)^{* * *}$ & $0.0181(0.74)$ \\
CURR & $0.0014(3.56)^{* * *}$ & $0.0012(8.00)^{* * *}$ & $0.0012(0.82)$ \\
TDTA & $-0.0047(-12.97)^{* * *}$ & $-0.0045(-14.70)^{* * *}$ & $-0.0045(-0.97)$ \\
LnTA & $0.0050(1.11)$ & $0.0019(0.46)$ & $0.0019(0.05)$ \\
Cons & $0.6546(8.55)^{* * *}$ & $0.7022(8.48)^{* * *}$ & $0.7022(0.51)$ \\
& & & \\
Sargan Test & $24.3287[0.6120]$ & $12.1799[0.9936]$ & \\
AR(1) & & $-1.3304[0.1834]$ & $-0.0970[0.9227]$ \\
AR(2) & & $-0.7755[0.4380]$ & $-0.1279[0.8982]$ \\
\hline
\end{tabular}

Figures in parenthess ( ) are t-statistics, except for Sargan test and ArellanoBond test [ ] for serial correlation, which are p-values. ${ }^{* *}$ and ${ }^{* * * *}$ indicate the respective 5\% and 1\% significance level

In this part, we present the results of accounting information determinants of merton distances-to-default. Table 4 above presents the results of the dynamic panel data estimation approach. At first, we have one-step difference GMM model (GMM-dif) which includes variables of ROE, ROIC, NIM, CASHR, CURR, TDTA, and LnTA. At the later stage, we also show system GMM (GMM-syst). 
Based on GMM-dif results, we find that profitability proxies (as indicated by return on equity, return on investment capital, and net income margin), liquidity proxies (as depicted by cash ratio and current ratio), debt to asset ratio (TDTA), and lagged dependent variables $\left(\right.$ Merton $_{i t-1}$ ) are statistically significant with merton distances-to-default. ROE, cash ratio, and current ratio are positive, as expected, and statistically significant for Merton distance to default while ROIC, NIM, and TDTA load are negatively significant for the measurement, indicating that a higher level of ROIC, NIM, and TDTA is associated with a lower level of Merton distances-to-default. Asset size (lnTA) has positive relationship with merton even though it is not significant for Merton default for all horizons.

Profitability ratio (as indicated by ROE) is an imperative determinant of Merton distance-to-default. More specifically, one per cent increase in ROE jacks up Merton-default by 0.001 . When the value of ROE goes up one per cent point, the Merton-default increases by 0.001 per cent point. In the same fashion, liquidity ratios (as indicated by CURR and CASHR) also play a crucial role in explaining Merton distance-to-default. As the CASHR and CURR increase by 1 percentage point, the Merton distance-to-default increases by 0.016 and 0.001 respectively. In the different style, when the asset size increase by one per cent point, the Merton distance-to-default decrease by 0.0047 . Moreover, the sargan test supports the findings of GMM approach. From sargan test, we cannot reject the null hypothesis (chi-square $=24.3287$, p-value $=0.6120$ ); hence, our restrictions imposed are valid.

Subsequently, we also show the GMM-syst estimation. According to the results, GMM-dif and GMM-syst produce quite consistent results, which affirm Blundell and Bonds (1998), indicating that the performance of GMM-dif improves with the number of time series observations. To some extent, the parameters for accounting variables observed under GMM-dif are persistently greater than that parameters estimated for GMMsyt. The coefficient for profitability ratios, liquidity ratios, debt to asset ratio, and lagged variable remains significant at the alpha 5\%; meanwhile, firm size, albeit showing positive relationship, is not 
statistically significant. We perform auto-correlation test for GMMsyst. In that, we cannot reject the null hypothesis at order-1 $(\mathrm{Z}=$ 1.33, $\mathrm{p}=0.1834)$ and order $2(\mathrm{Z}=-0.755$ and $\mathrm{p}=0.4380)$; hence, there is no autocorrelation problems in our GMM-syst model. In addition, there is no second-order serial autocorrelation in our GMM estimation; hence, we satisfy the GMM requirements to produce consistent results. On top of that, our study satisfies all of diagnostic tests of sargan test and autocorrelation test.

\section{Conclusion}

Based on the Merton default-to-distance for the period 2005 to 2013, the study observes that, in most cases, the default probability of non-sharia companies observed are greater than 0.5 . The highest default probability for companies observed is Bank Central Asia (BCA) of 1.00 for the year 2005 to 2007 and 2009 to 2012, almost consistent for the years observed. This finding is consistent with the study of Konstituanto et al. (2011) which reveals that the BCA has the highest probability to default among the banks observed in year 2006 to 2009. They also indicate that BCA has the highest level of volatility for the share price among the sample observed. On the other hand, the lowest default probability in our study falls in Berlian Laju Tankers Tbk of 0.2480 for the year 2012. This company has the lowest probability level with the range of 0.2480 to 0.6220 .

This study examines the determinants of Merton distanceto-default using accounting information of profitability measures, liquidity measures, debt to asset, and company's size. Using GMM approach (GMM-dif and GMM-syt), the results find that profitability ratios (ROE, ROIC, NIM), liquidity ratio (CASHR, CURR), debt asset ratio, and lagged dependent variable $\left(\right.$ Merton $\left._{i t-1}\right)$ are found to be statistically significant determinants of merton distance-to-default. The company size is not a good predictor of the default risk for companies observed. The result of study emphasizes the benefits of using several accounting-based measures in company-default prediction models. 


\section{Reference}

Amin, Ma'ruf. 2011. Kajian Fiskal, Moneter, Ekonomi dan Keuangan: Bursa Syariah Tahan Krisis, diposkan dalam http://makmunr. blogspot.com/2011/09/bursa-syariah-tahan-krisis.html

Ardiansyah, Misnen, and Abdul Qoyum. 2010. Default Risk in Islamic Equity Return (the Case of Kuala Lumpur Stock Exchange). Journal of Global Business and Economic Research, Vol. 1 (1): 180-211.

Asian Development Bank (ADB). 1999. Asian Development Outlook 1999, Manila: Asian Development Bank.

Beaver, W. H. 1966. "Financial Ratios as Predictors of Failure." Journal of Accounting Research, Vol. 4: 71-111.

Black, F and Scholes, M. 1973. On the Pricing of Options and Corporate Liabilities. Journal of Political Economy, Vol. 81, May-June: 637-54.

Brigham, Eugene F., Ehrhardt, Michael C., 2005. Financial Management: Theory and Practice, 11th ed., Thomson, USA.

Casey, C. \& Bartczak, N. 1985. "Using Operating Cash Flow to Predict Financial Distress: Some Extensions." Journal of Accounting Research, Vol. 23 No. 1, pp. 384-401.

Corsetti, G., Pesenti, P., \& Roubini, N. 1999. What Caused the Asian Currency and Financial Crisis? Japan and the World Economy, Vol. 11, pp. 305-373.

Chongvilaivan, A. 2010. Global Financial Crisis and Growth Prospects in Asia-Pacific: A Sectoral Analysis. Paper presented at The 26th Conference of the American Committee for Asian Economic Studies, Kyoto, Japan, 5-6 March.

Davis, E.P. 1994. Market Liquidity Risk, Kluwer Academic Publishers.

Davis, E.P. 2001. A typology of Financial Instability, Oesterreichsche National Bank Financial

Dewi, Friderika Widyasari (Direktur Pengembangan Bursa Efek Indonesia) (2011), Kajian Fiskal, Moneter, Ekonomi dan Keuangan: Bursa Syariah Tahan Krisis, diposkan dalam http://makmunr.blogspot. com/2011/09/bursa-syariah-tahan-krisis.htm

Diamond, D., Dybvig, P. 1983. Bank Runs, Deposit Insurance and Liquidity. Journal of Political Economy. vol. 91: 401-419.

Eisenhardt, K. M. 1988. "Building Theories from Case Study Research." Academy of Management Review, Vol. 14, No.4: 532-550 
Fisher, I. 1933. The Debt Deflation Theory of Great Depressions. Econometrica, Vol. 1: 337-357.

Herring, J. 1999. Credit Risk and Financial Instability. Oxford Review of Economic Policy, Vol.15, No. 3: 63-67.

Gitman, J. Lawrence, 2006. Principles of Managerial Finance, 10th Edition

Grunert, J., Norden, L. \& Weber, M. 2005. The Role of Non-Financial Factors in Internal Credit Ratings. Journal of Banking and Finance, Vol. 29: 509-531

Merton, R. C. 1974. On the Pricing of Corporate Debt: The Risk Structure of Interest Rates. Journal of Financ, Vol. 29 (2): 449-470

Qu, Yiping. 2008. Macro-economic Factors and Probability of Default. European Journal of Economics, Finance and Administrative Sciences. ISSN 1450-2275, Issue 13.

Raz, Arisyi F., Tamarind P. K. Indra, Dea K. Artikasih, and Syalinda Citra. 2012. Krisis Keuangan Global dan Pertumbuhan Ekonomi: Analisa dari Perekonomian Asia Timur. Buletin Ekonomi Moneter dan Perbankan, Oktober.

Research Bank of Australia. 2012. About Financial Stability. Retrieved from http://www.rba.gov.au/fin-stability/about.html on 7 December 2012.

Ridwan, Muhtadi. 2011. Ketahanan Keuangan Syariah dalam Menghadapi Krisis Global Dan Kontribusinya atas Ekonomi Nasional Dan Ekonomi Global." Disampaikan pada Focus Group Discussion (FGD) Kementrian Keuangan Republik Indonesia Badan Kebijakan Fiskal Pusat Kebijkan Pembiayaan Perubahan Iklim dan Multilateral, Kamis, 3 November.

Research Bank of Australia. 2012. About Financial Stability. Retrieved from http:/www.rba.gov.au/fin-stability/about.html on 7 December 2012.

Sugiyono, 2008. Metode Penelitian Bisnis. Bandung: Alfabeta.

Tambunan, Tulus, Tahi Hamonangan. 2011. The Impact of the 20082009 Global Economic Crisis on A Developing Country's Economy: Studies from Indonesia. Journal of Business and Economics, March, Volume 2 (3): 175-197.

Tudela, Merxe, and Garry Young, 2003a. A Merton Model Approach to Assessing the Risk of UK Public Companies. Bank of England Working Paper: 194 
Tudela, Merxe, and Garry Young. 2003b. Predicting Default among UK Companies: A Merton approach. Bank of England Financial Stability Review, June 2003

Vassalou, Maria, and Yuhang Xing. 2004. Default Risk in Equity Returns. The Journal of Finance, Volume 59 (2): 831-868. 